\title{
DECLINE OF SOOTY SHEARWATERS, PUFFINUS GRISEUS, ON THE SNARES, NEW ZEALAND
}

\author{
by Darren Scott, Paul Scofield, Christine Hunter and David Fletcher
}

(with two text-figures and six tables)

\begin{abstract}
Scott, D., Scofield, P., Hunter, C. \& Fletcher, D. 2008 (31:x): Decline of Sooty Shearwaters, Puffinus griseus, on The Snares, New Zealand. Papers and Proceedings of the Royal Society of Tasmania 142(1): 185-196. https://doi.org/10.26749/rstpp.142.1.185 ISSN 0080-4703. Department of Zoology, University of Otago, Box 56, Dunedin, New Zealand (DS); Canterbury Museum, Rolleston Avenue, Christchurch, New Zealand (PS); CNSM/ LAB Biology and Wildlife Department, 211 Irving 1, University of Alaska, Fairbanks, Alaska, 99775, USA (CH); Department of Mathematics and Statistics, University of Otago, Box 56, Dunedin, New Zealand (DF*). *Author f•r correspondence. Email: dfletcher@maths.otago.ac.nz
\end{abstract}

The number of Sooty Shearwater, Puffinus griseus, burrow entrances on North East Island of The Snares, New Zealand, declined from 3288000 (95\% CI = 3.1-3.5 million) entrances between 1969 and 1971, to 2061000 (95\% CI = 1.9-2.2 million) between 1996 and 2001. This represents a decline of $37 \%$ over 27 years, or $1.72 \%$ per year $(95 \% \mathrm{CI}=1.35 \%-2.12 \%)$. It is not known whether burrow occupancy has also declined. Possible reasons for decline include fisheries bycatch, climate change, and losses on other islands to predation by introduced mammals and harvest of chicks (muttonbirding). Reliable population estimates of other Sooty Shearwater populations will be important for establishing baseline estimates against which future population trends can be evaluated. If the decline in burrow numbers represents a similar decline in Sooty Shearwater numbers on The Snares and elsewhere, the decline reported here is substantial and enough to warrant listing of the Sooty Shearwater as a "vulnerable" species, according to criterion A3 designated by the International Union for Conservaion of Nature and Natural Resources (IUCN) in 2001.

Key Words: Sooty Shearwater, Puffinus griseus, The Snares, population decline, fisheries bycatch, climate change, predation, harvest.

\section{INTRODUCTION}

Marine birds are sensitive to perturbations in climate, prey abundance and food-web structure. In recent decades increasing pressure has been put on the world's oceans from fisheries and global environmental changes associated with a burgeoning human population (Worm et al. 2006). Seabirds are increasingly being used as sensitive indicators of the state of the world's oceans (Furness \& Camphuysen 1997). Seabird population decline is widespread, with $50 \%$ of taxa in the largest group of marine birds, the Procellariiformes, listed by the IUCN as threatened, vulnerable or endangered (Collar et al. 1994).

Procellariiformes are long-lived, monogamous species with low reproductive output and delayed maturation (Warham 1990, 1996). Their populations are particularly sensitive to any fluctuation in adult survival (Danchin et al. 1995, Hamilton \& Moller 1995, Russell 1999). Demographic consequences of a significant mortality of breeding birds can therefore be rapid and severe, and recovery slow, e.g., the near extinction of the Black Petrel Procellaria parkinsoni G.R. Gray, 1862, on Little Barrier Island (Imber 1987). Maturation is delayed, so any change in fledging or juvenile survival may take a generation or more to be detectable in population trends (Fletcher et al. unpubl. data).

Sooty Shearwater (Tītī), Puffinus griseus (J.F. Gmelin, 1789), is a highly abundant trans-equatorial migrant seabird that plays a major role in the ecology of the islands of southern New Zealand and South America, where it breeds (Shaffer et al. 2006). The current total New Zealand population size is estimated to be 19-23 million individuals (Newman et al. unpubl. data). Chicks ("muttonbirds") are harvested by Rakiura Mãori (indigenous people) (see Kitson \& Moller 2008). Approximately 360000 chicks have been harvested annually in recent years (Newman et al. 2008). However, of indicators of Sooty Shearwater decline has been found. Harvest rates of Sooty Shearwater chicks on Poutama Island decreased by $42-47 \%$, or $3.6 \%$ to $3.9 \%$ per year, between 1989 and 1998 (Lyver et al. 1999). Furthermore, a $64.4 \%$ decline was found in the number of adult Sooty Shearwaters found dead on beaches in New Zealand between 1961 and 1999, or 1.3\% per year $(95 \% \mathrm{CI}=0.3 \%$ to $1.7 \%$ per annum) (Scofield \& Christie 2002). Declines have also been recorded elsewhere; for example Sooty Shearwater numbers in the Californian current system declined by $90 \%$, or $7.4 \%$ per year, between 1987 and 1995 (Veit et al. 1997).

Driftnet fishing for squid and salmon occurred in the North Pacific from 1978 until the end of 1992 (Uhlmann 2002, 2003, Uhlmann et al. 2005). Estimates of the impact of these fisheries on marine ecosystems vary. Sooty Shearwater and Short-tailed Shearwater, Puffinus tenuirostris (Temminck, 1835), were the largest component of the bycatch, both numerically and in biomass. Shearwaters may still be a major component of the bycatch in salmon fisheries in the North Pacific (Artyukhin \& Burkanov 2000). Ogi et al. (1993) predicted a population growth rate $(\lambda)$ of between 0.993 and 0.972 for the breeding stock of Sooty Shearwaters during the period driftnet fisheries operated. However, this estimate has not been confirmed by actual estimates of population trends at their breeding colonies (Warham 1996) and all the inputs to Ogi et al.'s (1993) model were from Short-tailed Shearwater.

The Snares $\left(48^{\circ} 01^{\prime} \mathrm{S}, 166^{\circ} 36^{\prime} \mathrm{E}\right)$ is a group of small islands lying $105 \mathrm{~km}$ south-southwest of Stewart Island, New Zealand. Surveys conducted between 1969 and 1971 estimated that collectively these islands had a population of 2.75 million breeding pairs of Sooty Shearwater (Warham \& Wilson 1982). Our study repeats the counts undertaken by Warham \& Wilson (1982) on North East Island, the largest of The Snares islands. Burrow counts previously undertaken in $1986 / 87$ at 30 permanently marked vegetation plots are 
also repeated in this study. Our primary aim is to determine whether a measurable decline in the Sooty Shearwater breeding population has occurred in the decades since the original surveys were undertaken. We also estimate the generation time of Sooty Shearwaters from recently available population parameters and ask whether any decline observed on The Snares has reached the critical threshold that would lead to the species being listed as threatened according to IUCN (2001) criteria.

\section{MATERIALS AND METHODS}

\section{Study site}

North East Island, also referred to elsewhere as Main Island, is 238.1 ha in area. The principal habitat types on the island are Olearia lyallii Hook.f. (tree daisy) forest, and maritime tussock grassland dominated by Poa astonii Petrie and P. tennantiana Petrie (Warham \& Wilson 1982, Hay et al. 2004).

\section{Burrow entrance counts}

We define a burrow entrance as a single entrance leading to one or more tunnels (following Warham $\&$ Wilson 1982). Entrances may have more than one occupied tunnel and individual nests frequently have more than one entrance (McKechnie et al. 2007, Hamilton 2000). Assuming that the probability of detecting entrances in different areas and times does not change, this will not affect interpretation of relative trends in shearwater abundance.

There are about 10000 breeding pairs of Mottled Petrels, Pterodroma inexpectata (J.R. Forster, 1844), on The Snares (Warham et al. 1977). Mottled Petrel and Sooty Shearwater burrow entrances can be difficult to tell apart. Warham \& Wilson (1982) do not state how they separated Mottled Petrel and Sooty Shearwater burrows in their study; however we found that Mottled Petrel burrows were always in dry, open, well-drained sites. Additionally, no Mottled Petrel burrows were found in soil with a depth of greater than c. $50 \mathrm{~cm}$, and tunnels were rarely longer than an arm's length. Furthermore, burrow entrances of Mottled Petrels were smaller than those of Sooty Shearwater (Scott 2005, Scott et al. 2006), and were almost always in areas where Poa tussock was prevalent; only one occupied Mottled Petrel burrow was found more than $5 \mathrm{~m}$ from the Poa tussock strip that encircles the island.

We assumed that all burrow entrances with a maximum greatest entrance width of less than $7 \mathrm{~cm}$ were Common Diving-Petrel, Pelecanoides urinatrix (J.F. Gmelin, 1789). An estimate of the number of diving petrel burrows recorded during these surveys is given in Miskelly et al. (2001).

\section{9-71 surveys}

Warham \& Wilson (1982) sampled 51 quadrats, each 10 $\times 10 \mathrm{~m}$ and randomly placed off marked tracks, between 1969 and 1971. They assessed habitat type and estimated planar habitat size from a map produced in 1971 from aerial photographs (Hay et al. 2004). Random number tables were used to obtain distances along and off the track for quadrat placement. The approximate position of these tracks is given in Figure 1 of Warham (1967); however the locations of the quadrats were not permanently marked.

\section{Permanent vegetation quadrats, 1986/87}

The University of Canterbury established $3010 \times 10 \mathrm{~m}$ permanently marked vegetation quadrats in the summer of 1986/87. Only 23 quadrats contained recognisable burrows that were occupied. The primary purpose of these quadrats was to map vegetation change, but burrow entrance positions were plotted and the total numbers of entrances was counted.

\section{Burrow entrance surveys, 1996-2001}

In all 357 sampling units, with a combined area of $2.25 \mathrm{ha}$, were surveyed for burrow entrance density during the late incubation period between 1996 and 2001 . Four methods of plot establishment and size were used to address related research questions, described elsewhere (Scofield 2000, Charleton 2002).

\section{Quadrats positioned from tracks}

Random numbers were used to select a distance along and off the track system for placement of $10 \times 10 \mathrm{~m}$ plots in Dec-Jan $1996(\mathrm{n}=60)$.

\section{Transects positioned from tracks}

In Dec-Jan 1996, random numbers were used to select a distance along and off the track system for placement of 2 -m-wide transects. Transects followed a randomly-assigned direction until 20 used burrow entrances were included and transect length was then recorded to provide an estimate of entrance density $(\mathrm{n}=45)$.

\section{Quadrats positioned along transects across the island}

Three randomly-placed line transects were chosen, running approximately north-south, east-west and southeastnorthwest actoss the entire island (fig. 1). Plots measuring $10 \times 10 \mathrm{~m}$ were placed every 100 paces along the transects in January $2000(\mathrm{n}=101)$.

\section{Circular plots along transects near coast}

Random numbers were used to obtain start points for 18 transects (nine each on the east and west coast) that ran perpendicular to the coast. Circular plots of $3 \mathrm{~m}$ radius were placed at intervals of $3,15,27,54,76,113$ and 174 paces from the coast in January $2001(\mathrm{n}=151)$.

In addition to the 357 sampling units above, the Sooty Shearwater burrow entrances within the 23 University of Canterbury permanent vegetation quadrats recorded with burrow entrances in 1986/87 were counted in December 1998.

The locations of all sampling units on North East Island are shown in figure 1 . We assessed vegetation type, whether the ground cover was open or closed and recorded the number of Sooty Shearwater entrances that were open, and the number of Common Diving-Petrel and Mottled Petrel entrances in each sampling unit. The position of each sampling unit was recorded using a Trimble Geo-explorer II "differential GPS unit and mapped in Geographical Information System MapInfo 6.0 ${ }^{\mathrm{Tx}}$, on a base map supplied by Land Information New Zealand. Vegetation boundaries and types were digitised from a map produced from aerial photographs taken in 1971 (Hay et al. 2004). This allowed the land area under each vegetation type to be calculated and mapped. During the 2000 and 2001 surveys, this map was "ground truthed" in the field to determine changes in 


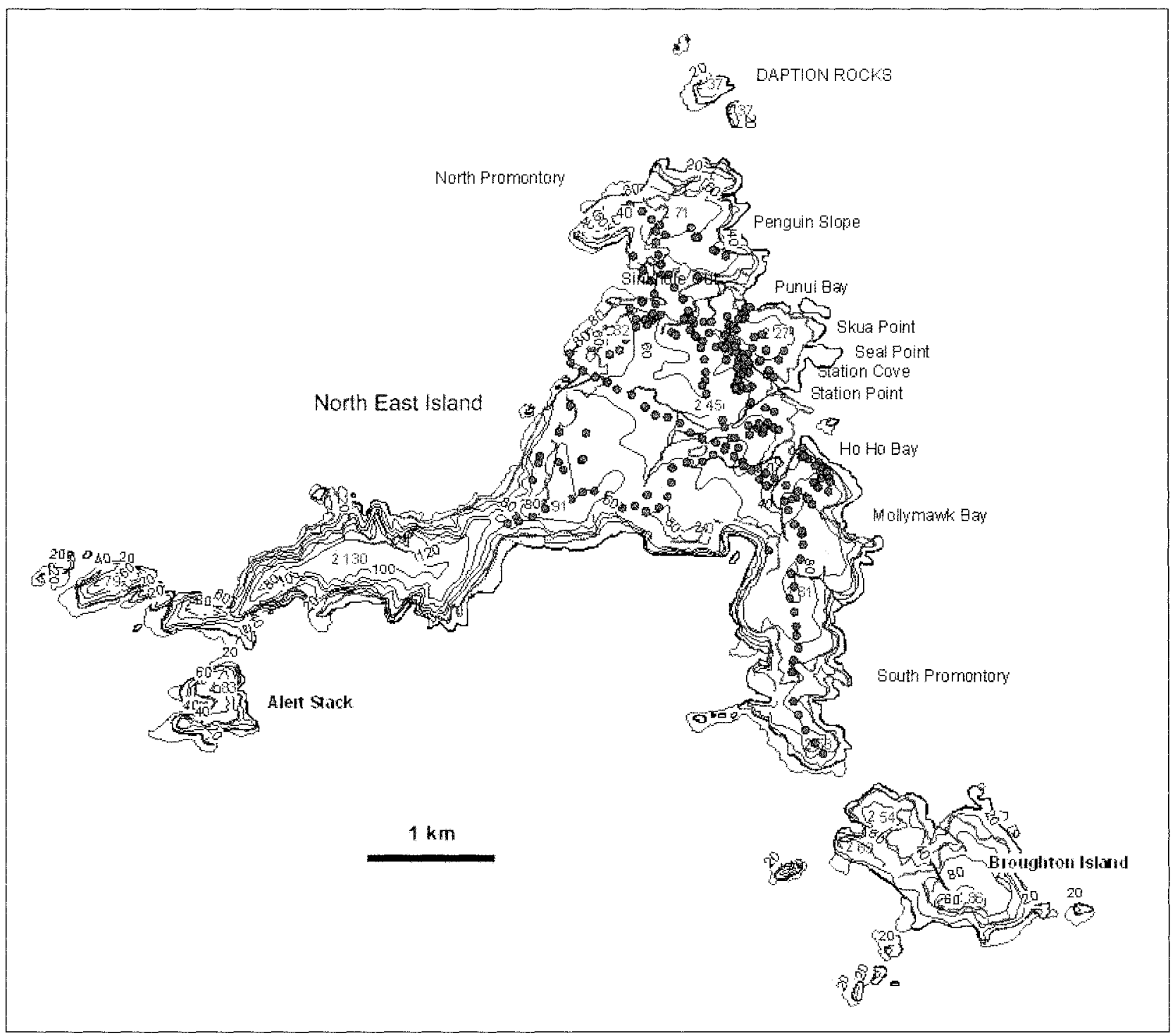

FIG. 1 - North East Island, The Snares, with locations of sampling units (circles) surveyed for Sooty Shearwater burrow entrances 1996-2001.

vegetation cover since 1971 . Changes in vegetation cover were found to be minor, with a small decrease in the area classified as Olearia forest and increase in the area classified as Hebe elliptica shrubland (table 1). The estimated area of the island available for Sooty Shearwater burrows excluded the area occupied by penguin colonies. A survey of Snares Crested Penguin, Eudyptes robustus Oliver, 1953, detailing colony sizes and locations undertaken in October 2000 (D. Houston, unpubl. data) was used to exclude these areas from the estimated burrowable area of the island.

\section{Burrow occupancy}

The proportion of Sooty Shearwater burrows in which breeding was evident (egg or chick) is referred here as the "occupancy rate". This has been assessed in three general and five specific ways throughout the studies compared here.

\section{Contents of collapsed nesting chambers}

Whilst carrying out fieldwork on The Snares it is difficult to avoid accidentally collapsing burrows that are often situated in fragile soils. Warham \& Wilson accidentally collapsed 54 nesting chambers between 3 December 1970 and 24 February 1971. During our study, 86 burrow chambers were collapsed between 26 December 1999 and 20 January 2000; and 62 chambers between 10 January and 5 February 2001. All burrows were carefully reconstructed using available materials, but first the contents (egg or chick) were determined.

\section{Burrowscoping}

A burrowscope consists of a miniature surveillance camera on the end of a long tube that projects an image of the nesting chamber onto a monitor on the surface (Lyver et al. 1998). We used burrowscopes to estimate burrow occupancy on the 452 -m-wide transects ( 900 burrow entrances) positioned from tracks between December-April 1996 and 1998.

\section{Measures of passage into and out of burrow entrances in January}

Comparisons are possible between two methods: (i) Horning (1976) and Warham \& Wilson (1982) estimated occupancy by observing the disturbance of fine wires placed across the 31 burrow entrances between 4 and 22 January 1972. (ii) We used an electronic burrow monitoring system (based 
TABLE 1

Sooty Shearwater burrows by vegetation type on North East Island, The Snares

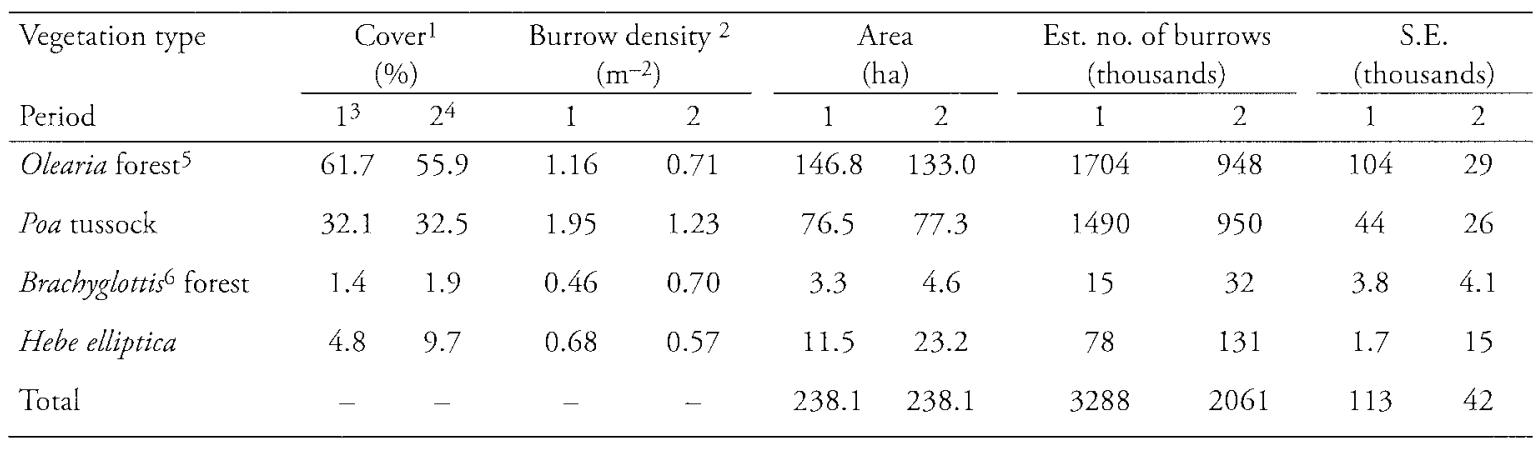

I Cover is the percentage of the island covered by that vegetation type.

2 Burrow density is the estimated mean density of burrow entrances.

3 Period 1 data were collected between 1969 and 1971 (from Warham \& Wilson 1982).

4 Period 2 data were collected between 1996 and 2001.

5 Includes vegetation from areas in which Olearia was present with other vegetation.

6 Formerly Senecio.

on an off-the-shelf burglar alarm system) to record the date and time of entrance and exit events from manual triggering of switches placed in the burrow entrance (Moller et al. 2003a). One panel could monitor 16 separate entrances and up to four panels were used simultaneously during this study. Thirty-two of these automated entrance monitors operated at two study sites near Punui Bay between 10-22 January 1999 and 4-22 January 2000.

\section{Measures of passage into and out of entrances in April}

(i) Horning (1976) and Warham \& Wilson (1982) estimated occupancy of 100 entrances chosen at random under Olearia forest near Punui Bay in April 1970. In early April, they determined occupancy by feeling for an occupant by hand or by using a long wire.

(ii) In late April, the knocking down of thin wires placed in the burrow entrance, evidence of fresh digging, presence of nestling down in the tunnel, and observation of birds entering these 100 entrances were all used to assess occupancy.

(iii) We used the electronic entrance monitoring system to quantify use of 15 occupied and 17 unoccupied burrows between 1-30 April 1998; and 11 occupied and 21 unoccupied burrows between 1-30 April 1999.

\section{Surface egg density}

Some Sooty Shearwater eggs are laid on the ground outside burrow entrances ("surface eggs"). These can be easily distinguished from eggs which have been ejected from burrows, as the latter are generally dirty and stained by incubation and rolling. Warham et al. (1982) estimated the number of surface eggs at two sites of differing burrow entrance density near Punui Bay throughout the 1970 egg laying period. We searched six sites in 1998, varying in size from 100-1600 $\mathrm{m}^{2}$, which were randomly located within Olearia habitat type and in reasonable proximity to the research hut in the Boat Harbour. One of the six sites was excavated for another study in 1996 (Hamilton 2000).

\section{Statistical methods}

We used single factor ANOVA to compare the burrow entrance density estimates obtained using four sampling methods (quadrats, transects, quadrats from line transects and circular plots) in the Olearia vegetation type. We used stratified sampling methods (Cochran 1977) to estimate the standard error associated with the estimate of the total number of burrows in the different time periods, the strata being the different vegetation types. All analyses were carried out in a Microsoft Excel spreadsheet.

\section{Generation time}

One of the IUCN (2001) criteria used to determine whether a species is classed as "vulnerable" is a decline of $\geq 50 \%$ over the last 10 years or three generations (criterion A1). We estimated the generation time $(T)$ of Sooty Shearwater using a standard formula, based on the assumption that all breeding adults have the same reproductive rate and the same survival rate, i.e.,

$$
T=\alpha+[s /(\lambda-s)]
$$

where $\alpha$ is the age at first breeding (assumed the same for all birds), $s$ is the breeder survival rate, and $\lambda$ is the population growth rate (Gaillard et al. 2005). There are no published data on the age at first breeding for Sooty Shearwater, so we used an estimate for a closely-related species, Short-tailed Shearwater (Bradley et al. 1989).

\section{RESULTS}

\section{Burrow entrance counts}

During the survey period 1969-71, the density of Sooty Shearwater burrow entrances in different vegetation types ranged between 0.46 and 1.95 entrances per $\mathrm{m}^{2}$ (Warham \& Wilson 1982, table 1). Using aerial photographs and a vegetation map, Warham \& Wilson (1982) estimated the total planar area of North East Island to be $280 \mathrm{ha}$. Excluding 
areas devoid of soil, they estimated the burrowable area of the island to be 238.1 ha. The area occupied by Snares Crested Penguins was not considered by Warham \& Wilson (1982) (K-J. Wilson pers. comm.). The October 2000 survey of Snares Crested Penguins counted 25851 nests. Each penguin nest occupied approximately $1 \mathrm{~m}^{2}$ (D. Houston pers. comm.), so penguins make c. 2.6 ha unavailable to Sooty Shearwaters.

Three of the methods used to survey burrow entrances in 1996-2001 were not specifically stratified to sample representative vegetation types. Burrow density from all four methods (quadrats, transects, quadrats from line transects and circular plots) could therefore only be compared in the Olearia vegetation type. There was evidence for a difference in the burrow density estimates found using the four counting methods $(F=4.66$, with 3 and 168 d.f.; $P=0.004)$, but the differences were small (table 2). Thus, we combined the burrow entrance density estimates from the four methods to generate the most accurate estimate of burrow density possible for 1996-2001. The density of burrow entrances in different vegetation types ranged from 0.57 to 1.23 entrances per $\mathrm{m}^{2}$ (table 1). The estimated total number of Sooty Shearwater burrow entrances on North East Island during our study between 1996 and 2001 is 2.06 million $(95 \% \mathrm{CI}=1.9$ to 2.2 million) (table 1$)$.

\section{Changes in burrow entrance density}

We estimate a decrease of approximately 1.23 million Sooty Shearwater burrow entrances ( $95 \% \mathrm{CI}=0.95-1.51$ million) has occurred between 1969/1971 and 1996/2001. This represents a decline of $37 \%$ over 27 years, or $1.72 \%$ per year $(95 \% \mathrm{CI}=1.35-2.12 \%)$.

Burrow entrance density for the 23 permanent vegetation quadrats that contained burrow entrances in 1986 decreased from 1.34 entrances per $\mathrm{m}^{2}(\mathrm{SE}=0.23)$ to 1.09 entrances per $\mathrm{m}^{2}(\mathrm{SE}=0.20$ ) between 1986 and 1998 , respectively. The 95\% CI for the decrease was $0.05-0.45$ entrances per $\mathrm{m}^{2}$. This represents a decline of $19 \%$ over 12 years, equivalent to an annual decline of $1.71 \%$ per year $(95 \%$ $\mathrm{CI}=0.51-3.09 \%)$.

\section{Conservation status of Sooty Shearwater}

Bradley et al. (1989) report an estimate of age at first breeding for Short-Tailed Shearwater of 7.0 years $(S E=1.1)$. They also provide an estimate of adult survival rate of $0.92(\mathrm{SE}=$ 0.01 ). The only published estimate of breeder survival rate for Sooty Shearwater is 0.87 (95\% CI: 0.80-0.94), given by Scofield et al. (2001).

If we use the estimates of the age at first breeding $(\alpha)$ and breeder survival rate (s) from Bradley et al. (1989), together with the estimate of $\lambda=0.983$ (95\% CI: $0.979-0.987)$ implied by a $1.7 \%$ decline in burrow density, we obtain an estimate of the generation time $(T)$ of 21.6 years $(95 \% \mathrm{CI}$ : 17.2-29.3). We used parametric bootstrapping, with 10000 replicates, to determine the confidence interval for $T$ and for the decline over three generations (Davison \& Hinkley 1997). On this basis, we estimate that the observed $1.7 \%$ annual decline of Sooty Shearwater burrow entrances equates to a $67 \%$ decline over three generations ( $95 \% \mathrm{CI}: 54-81 \%$ ). Using the estimate of adult survival for Sooty Shearwater from Scofield et al. (2001), we get a value for $T$ of 14.7 years (95\% CI: 10.7-28.5), which leads to an estimated 53\% decline over three generations (95\% CI: $40-78 \%$ ).
TABLE 2

Sooty Shearwater burrow entrance density on North East Island, The Snares during 1996-2001, for sampling units classified as having the Olearia vegetation type

\begin{tabular}{lccc}
\hline Sampling unit $^{1}$ & $\begin{array}{c}\text { Burrow density } \\
\left(\mathrm{m}^{-2}\right)\end{array}$ & S.E. & $\mathrm{n}$ \\
\hline Quadrats & 1.15 & 0.11 & 6 \\
Transects & 1.05 & 0.05 & 25 \\
Quadrats from line & 1.16 & 0.04 & 38 \\
transects & & & \\
Circular plots & 0.98 & 0.03 & 103 \\
\hline
\end{tabular}

${ }^{1}$ Four types of sampling units were used.

2 Burrow Density is the estimated mean density of burrow entrances.

Does not include observations from areas in which Olearia was present with other vegetation (cf. table 1).

\section{Burrow occupancy}

There is no evidence of a decline in the occupancy of nest chambers that were accidentally collapsed between 1971 and 1999/2000 (table 3; greatest difference $\chi^{2}=1.66$; d.f. $=1 ; \mathrm{P}=0.20$ ).

Similarly, there was little difference in the frequency of entrance events in January of 1972, 1999 and $2000\left(\lambda^{2}\right.$ $=1.359$; d.f. $=1 ; \mathrm{P}=0.244)$. Entrances containing an egg or chick were entered an average of $59.7 \%$ of nights, whereas those without eggs or chicks were entered $79.2 \%$ of nights ( $t=2.055$, d.f. $=26, \mathrm{P}<0.05$; fig. 2 ). Entrances in which breeding had failed, or in which an egg had never been laid, had very frequent visits, whilst those that contained a chick were less frequently visited. We conclude that frequency of entrance events in January cannot reliably indicate occupancy, so comparison between 1972 and recent estimates of activity cannot indicate changes in burrow occupancy.

Eighty-six per cent of entrances investigated in April 1972 had some indication of use that Horning (1976) and Warham \&Wilson (1982) interpreted as indicative of occupation by a chick. Between 1 and 30 April 1999, 36.1\% (s.d. $=10.0 \%$,

TABLE 3

Occupancy rate $(\%)$ of burrows accidentally collapsed on North East Island, The Snares

\begin{tabular}{|c|c|c|c|}
\hline & $\begin{array}{l}1971^{1} \\
(n=54)\end{array}$ & $\begin{array}{c}1999 \\
(n=86)\end{array}$ & $\begin{array}{c}2000 \\
(n=62)\end{array}$ \\
\hline Adult on egg & 55.6 & 45.3 & 45 \\
\hline Adult, no egg & - & 19.8 & 8 \\
\hline Two adults, no egg & - & 1.2 & 3 \\
\hline One or two adults, no egg & 18.5 & - & - \\
\hline Abandoned egg & 0.0 & 1.2 & 6 \\
\hline Occupancy rate & 74.1 & 67.5 & 61.3 \\
\hline Mottled Petrel ${ }^{2}$ & 0.0 & 1.2 & 0 \\
\hline
\end{tabular}

${ }^{1}$ Data for 1971 are from Warham \& Wilson (1982).

2 Data are for Sooty Shearwaters unless otherwise indicated. 


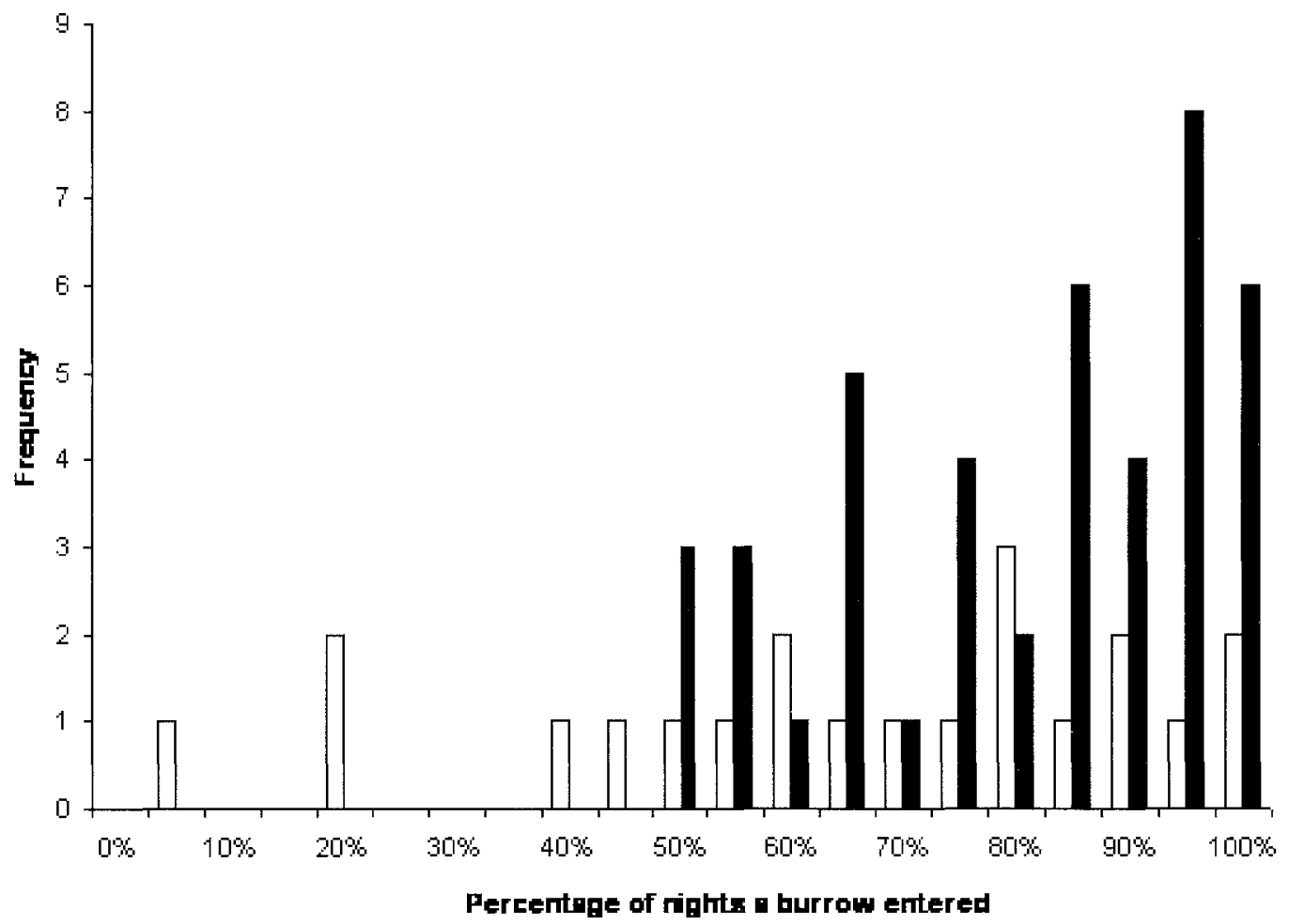

FIG. 2 - Frequency of Sooty Shearwater burrow entrance events per night, North East Island, The Snares. Dark bars represent burrows without chicks, open bars burrows with chicks. Sixty-four burrows were monitored over 19 nights; $4-22$ January 2000 (From Moller et al. 2003a).

range $18.8-56.3 \%$ ) of 32 entrances monitored each night were active. Overall $94 \%$ of 32 burrows were visited at least once. Fifteen of these entrances contained chicks or eggs in the 1999/2000 season and 11 did so in April 1999. Nonbreeders were absent from the colony during this period (Richdale 1954, R.P. Scofield unpublished. data). It would appear therefore that the true level of occupancy in 1972 may have been closer to half that reported. Explanations for overestimation of occupancy in 1972 include detection of wandering chicks or breeding adults which have holed up overnight in empty burrows after they have fed their chicks. The latter behaviour has been observed in Sooty Shearwaters elsewhere (G. Taylor pers. comm). Given this result, it is significant that only 42 entrances $(51 \%$ of the 82 thought to be occupied) had direct evidence that a burrow was occupied (a chick was felt by hand or with a wire) in 1972. There was no evidence that the occupancy estimate in 1972 was different from the average burrowscope estimates of occupancy in the late chick phase in 1996-2000 ( $t=$ -1.685; d.f $=8, \mathrm{P}=0.13$; tables 4, 5).

Methodological variations make interpretation of the above results extremely difficult. Furthermore, published estimates of occupancy on The Snares using burrowscopes with similar operators and methods indicate high variability between years and sites (table 4, Hunter 2001). Therefore, it is not possible to infer changes over time in average burrow occupancy from the data available.

\section{Surface egg density}

There was no evidence of a decline in surface egg density between 1970 and 1998 ( $t=0.015$; d.f. $=6 ; \mathrm{P}>0.89$; table 6). Similarly, there was no evidence that the mean number of surface eggs per burrow entrance changed $(t=0.0 .32$; d.f. $=6 ; \mathrm{P}>0.76$; table 6 ).

\section{DISCUSSION}

\section{Burrow occupancy}

Our monitoring of entrances of occupied and empty burrows using an electronic system showed that estimates of traffic in and out of entrances is not a reliable indicator of occupancy by breeding Sooty Shearwaters, especially in the middle of the breeding season. Hamilton (1998) reached a similar conclusion from her mainland New Zealand studies using stick barricades at burrow entrances. Entrances that were visited frequently are more likely to contain failed breeders or prospecting birds than breeders (fig. 2). The supposition that burrows with activity at the entrance in April contained chicks (Horning 1976, Warham \& Wilson 1982) was based on the assumption that chicks in the period from first emergence to fledging are faithful to their natal burrow. Traditional Ecological Knowledge of the Rakiura muttonbirders (Charleton 2002) and radio-tracking (C.M. Hunter unpubl. data) showed that chicks wander and explore other burrows from mid- to late April. Entrances in areas close to "take-off points" such as Punui Bay on North East Island, where one of our automatic monitoring plots was concentrated, are likely to have the highest level of unoccupied burrow visitation.

There is the potential for bias in the estimation of burrow occupancy rates from the inspection of collapsed burrows. Burrows close to the surface are more likely to collapse. If these burrows are favoured for breeding, then occupancy 
TABLE 4

Occupancy rate (\%) of Sooty Shearwater burrows on

North East Island, The Snares, from burrowscope data, by breeding stage and vegetation type (from Hunter 2001)

\begin{tabular}{llccc}
\hline Year & $\begin{array}{c}\text { Breeding } \\
\text { stage }\end{array}$ & \multicolumn{3}{c}{ Estimated burrow occupancy rate (\%) } \\
\cline { 3 - 5 } & & Poa tussock & Olearia forest & Fern \\
\hline 1996 & Incubation & 42.2 & 65.9 & 50.5 \\
1997 & Incubation & 11.1 & 28.8 & 17.1 \\
1998 & Incubation & 25.9 & 34.3 & 36.7 \\
1996 & Early chick & 30.7 & 48.3 & 34.9 \\
1997 & Early chick & 5.6 & 12.8 & 6.0 \\
1996 & Late chick & 43.8 & 48.1 & 33.2 \\
1997 & Late chick & 10.8 & 11.6 & 1.0 \\
1998 & Late chick & 21.9 & 22.9 & 16.2 \\
\hline
\end{tabular}

TABLE 5

Indications of Sooty Shearwater occupancy in 100 monitored burrows on The Snares, in April 1972 (from Horning 1976)

\begin{tabular}{|c|c|c|c|c|}
\hline & \multirow{2}{*}{$\begin{array}{l}\text { Only indication } \\
\text { of occupancy }\end{array}$} & \multicolumn{3}{|c|}{ Additional indication of occupancy } \\
\hline & & Down & $\begin{array}{l}\text { Bird felt with } \\
\text { wire loop }\end{array}$ & Digging \\
\hline \multicolumn{5}{|c|}{ No indication of occupancy $=14$} \\
\hline Bird felt with wire loop & 36 & 1 & - & 1 \\
\hline Bitten hand & 6 & - & - & - \\
\hline Wire fence disturbed & 15 & 13 & 3 & - \\
\hline Fresh digging & 6 & - & - & - \\
\hline Down in burrow mouth & 4 & - & - & - \\
\hline Bird seen entering burrow & 1 & - & - & - \\
\hline
\end{tabular}

TABLE 6

Density of Sooty Shearwater eggs laid on the ground outside burrow entrances ("surface eggs") at sites on North East Island, The Snares, in 1970 and 1998

\begin{tabular}{lccccc}
\hline Sice & Area $\left(\mathrm{m}^{2}\right)$ & $\begin{array}{c}\text { Burrow entrance } \\
\text { density }\left(\mathrm{m}^{-2}\right)\end{array}$ & $\begin{array}{c}\text { Number of surface } \\
\text { eggs }\end{array}$ & $\begin{array}{c}\text { Surface egg density } \\
\left(\mathrm{m}^{-2}\right)\end{array}$ & $\begin{array}{c}\text { Surface eggs per } \\
\text { burrow entrance }\end{array}$ \\
\hline 1998 & 600 & 0.52 & 8 & 0.013 & 0.026 \\
$\mathrm{~A}$ & 400 & 1 & 9 & 0.023 & 0.023 \\
$\mathrm{~B}$ & 100 & 0.91 & 4 & 0.040 & 0.044 \\
$\mathrm{Cl}$ & 650 & 0.61 & 11 & 0.017 & 0.028 \\
$\mathrm{D}$ & 600 & 0.81 & 7 & 0.012 & 0.014 \\
Low burrow density & 1600 & 1.1 & 20 & 0.013 & 0.011 \\
High burrow density & & & & 0.018 & 0.025 \\
19702 & 3160 & 0.73 & 58 & 0.019 & 0.018 \\
Low burrow density & 2860 & 1.06 & 55 & & \\
High burrow density & & & & & \\
\hline
\end{tabular}

${ }^{1}$ Disturbed site (Hamilton et al.1998).

2 Data for 1970 are from Warham et al. (1982). 
rates may be overestimated. Conversely, if these burrows are less favoured, then occupancy could be underestimated. Additionally, ateas with greater breeding success may have more burrows closer to the surface. Estimates of burrow occupancy from detection of chicks when felt by hand or with the use of a wire also have limited accuracy. A comparison gave no evidence for a difference between Warham \& Wilson's (1982) and our burrow occupancy estimates. However, these comparisons will have had low statistical powet because of the large variation in occupancy between years (table 4 and McKechnie et al. 2007) which results from large inter-annual variation in the proportion of adults laying eggs and breeding success (Newman et al. 2008, Newman et al. in press). Therefore we have no evidence that there has been decline or increase in burrow occupancy.

Density of breeding burrow entrances provides a stable index of breeding density that smoothes out inter-annual variation in burrow occupancy (Newman et al. 2008). There is also a close relationship between absolute chick density (as estimated by the burrowscope) and burrow entrance density on different islands and within family muttonbirding territories (Newman et al. 2008). Therefore it is most likely that changes in burrow entrance density that we observed on North East Island reflect a commensurate change in actual density of Sooty Shearwater breeding pairs during the interval between our studies.

\section{Decline of Sooty Shearwaters}

Our study confirms that the number of Sooty Shearwater burrow entrances on North East Island, The Snares, has declined markedly in the past 30 years. Although there was no evidence that the number of surface eggs has also declined, results for this measure are inconclusive because of large variation in the number of surface eggs between areas and the small number of areas and years sampled. The Traditional Ecological Knowledge of the Rakiura muttonbirders records that the number of surface eggs fluctuates markedly between years ( $H$. Moller unpubl. data), so a much longer run of observations will be needed to determine whether or not the number of surface eggs has changed.

There is strong evidence that the decline documented here is not restricted to The Snares islands and that the causes of the decline may also be affecting other populations of Sooty Shearwaters and other shearwater species. A 90\% decline in Sooty Shearwater numbers observed in the Californian current system over the period 1987-1994 (Veit et al. 1997) has been attributed to water temperature variations and climate change, but changes in bird distribution within the counting zone may have contributed (Oedekoven et al. 2001). Declines in Sooty Shearwater populations documented on the New Zealand mainland (Hamilton et al. 1997, Jones 2000) have been attributed primarily to predation by introduced small mammals. Various islands in the Hauraki Gulf of the North Island of New Zealand held small populations of Sooty Shearwaters until at least the 1960s (Falla 1934 and Department of Conservation banding records) that have now gone (R. Pierce, A. Booth and G. Taylor pers. comm., R.P. Scofield unpubl. data). An estimated 80 breeding pairs were recorded on Motunau Island, North Canterbury, in 1962 (Taylor 1967) although Scofield (2000 unpubl. data) found this population to be virtually extinct. It is significant that some of these declines or local extinctions have occurred in the absence of introduced predators or harvest, as observed in this study on The Snares and recently on Whenua Hou (Lyver et al. 1999). Recent declines in closely-related species, incuding Short-tailed Shearwater (Walsh et al. 1997), Fleshy-footed Shearwater, Puffinus carneipes (Gould, 1844), (Scofield 2000) and Pinkfooted Shearwater, Puffinus creatopus (Coues, 1864), (Ainley et al. 1995), have also been documented.

\section{Possible reasons for the Sooty Shearwater decline}

It is impossible to isolate a single cause for the decline in Sooty Shearwaters. Although the North Pacific squid fishery ceased in 1992 (Uhlmann et al. 2005), salmon gill net fisheries have continued throughout the North Pacific and these fisheries still take large numbers of shearwaters (Artyukhin \& Burkanov 2000). Approximately $40 \%$ of shearwaters killed in the Japanese squid dtiftnet fishery were of breeding age (Ogi et al. 1991a, b). Shearwaters are longlived, monogamous species with a low reproductive output (Warham 1990, 1996). They take one or more seasons to develop a pair bond and only ever lay one egg per season (Richdale 1963, Skira 1991). Sensitivity analyses of shearwater demography have shown that population growth rate is most sensitive to any change in the tate of mortality of breeding age birds (Hamilton \& Moller 1995, Hunter et al. 2000). Ryan \& Boix-Hinzen (1999) found a consistent male bias in fisheries bycatch for a number of petrel species taken off South Africa. Sooty Shearwaters are killed in New Zealand trawl fisheries and al though the full extent of this mortality has not been quantified, it is known that the proportion of killed birds which are male is high (Robertson 2000). For example, $83 \%$ (95\% binomial confidence intervals $72.2-94.2 \%$ ) of a spatially - and temporally - representative sample of Sooty Shearwaters $(n=205)$ taken mostly in the New Zealand squid trawl fishery were males (C.J.R. Robertson and R.P. Scofield, unpubl. data). If this sex-biased mortality was due to competitive exclusion, a similar bias would be expected in the North Pacific bycatch; however the available data on the sex ratio of shearwaters killed in the North Pacific are not consistent (Gould et al. 2000).

Climate fluctuations such as the El Nino/La Nina Southern Oscillation and the Pacific Decadal Oscillation trigger short-term and medium-term shifts in wind and currents (Mantua et al. 1997, Salinger \& Mullan 1999) that impact on bird productivity and potentially survival, movements and distribution (Veit et al. 1997, Lyver et al. 1999, Shaffer et al. 2006). Diet sampling and tracking studies show that Sooty Shearwaters forage at the highly productive upwelling region at the Sub-Antarctic Front (SAF), the boundary between the cool, sub-Antarctic waters and the warmer sub-tropic waters (Weimerskirch 1998, Shaffer et al. 2006). It is believed that inter-annual and long-term increases in global heat mass may push the SAF southwards. Sea surface temperature (SST) has been increasing in the waters between $45^{\circ} \mathrm{S}$ and $20^{\circ} \mathrm{S}$ since 1961 (Hurrell \& Trenberth 1999) and average SST and chlorophyll a measured near Marion Island has increased (Hunt et al. 2001), probably as a result of the SAF moving southward. Decline in the number of Rockhopper Penguins, Eudyptes chrysocome (J.R. Forster, 1781), since 1940 on Campbell Island (Cunningham \& Moors 1994), Amsterdam Island (Guinard et al. 1998) and the Falklands (Bingham 1998), and associated declining oceanic productivity (Hilton $e t$ al. 2006), may relate in part to the position of the SAF. 
Accidental introduction of Black Rats, Rattus rattus (Linnaeus, 1758), to Taukihepa (Big South Cape) in 1963 (Bell 1978) may have suppressed Sooty Shearwater populations (Scofield \& Christie 2002, Moller et al. 2003b). Additionally, the introduction of Weka, Gallirallus australis (Sparrman, 1786), an endemic rail, to several Títi Islands in the early rwentieth century may have added to ongoing harvest pressure on chicks (see Kitson \& Moller 2008). However, the factors regulating shearwater populations and potential compensation for these added predation and harvest impacts are unknown (Moller 2006) and, in general, the impacts of added chick losses are likely to be much lower than predation of adults (Hamilton \& Moller 1995, Hunter \& Caswell 2005, Wilcox \& Donlan 2007, Finkelstein et al. 2008). If a high level of inter-island movement is typical for Sooty Shearwater populations, as seen for Short-tailed Shearwater (Skira 1991), The Snares population may be affected by population declines occurring elsewhere, potentially driven by predation by rats and Weka and harvesting of chicks.

New Zealand Sea Lions, Phocarctos hookeri (Gray, 1844), haul out up to $500 \mathrm{~m}$ from where they come ashore on The Snares, but reports of this species breeding here are rare. Sea Lions can compact the soil, crush burrow entrances and create wallows and mud pools. Most of our sampling units were situated within $500 \mathrm{~m}$ of Sea Lion haul-out locations. Populations of New Zealand Sea Lions are increasing (McNally 2001, 2002), and while we have little direct evidence of Sooty Shearwater failure attributable to sea lions, potential impacts on breeding success cannot be ruled out.

\section{Implications of Sooty Shearwater decline on the ecology of The Snares}

Sooty Shearwaters are a keystone species in the ecology of The Snares and other islands on which they breed (Warham 1996, Moller et al. 2000, Hawke \& Newman 2005). A decrease in burrow numbers will reduce soil aeration, erosion, evaporation of surface moisture, nutrient cycling, and composting, and may alter vegetation regeneration patterns. The impacts of a Sooty Shearwater decline on three threatened or endangered plants on The Snares (Lepidium oleraceum G. Forst., Anisotome acutifolia (Kirk) Cockayne and Stilbocarpa robusta (Kirk) Cockayne) are unknown. There are about 310 Southern Skua, Catharacta lonnbergi Matthews, 1912, on The Snares that consume a considerable number of Sooty Shearwaters (Miskelly etal. 2001). A reduction in overall Sooty Shearwaters may result in an increase in predation by skua on less common species. Reduced competition for burrows sites may allow marginalised species such as Mottled Petrels, Common Diving-Petrels, Broad-billed Prions, Pachyptila vittata (Forster, 1777), and Fairy Prions, Pachyptila turtur (Kuhl, 1820), to expand, and reduce egg failure in Snares Island Snipe Coenocorypha aucklandica huegeli (G.R. Gray, 1845) caused by Sooty Shearwater disturbance (Miskelly 1999).

\section{CONCLUSION}

\section{Conservation status of Sooty Shearwater}

The decline of Sooty Shearwater on The Snares is substantial and will potentially have far-reaching ecological consequences. One of the IUCN (2001) criteria used to class a species as "vulnerable" is a documented decline of $50 \%$ over the last 10 years or three generations (criterion A1, IUCN 2001). Our study documented the decline of Sooty Shearwater on North East Island during the past 27 years, between the initial and recent survey, but could not apportion the decline between the last 10 years and those preceding. Additionally, the 27 year period is equivalent to only one or two generations of this species. Therefore the documented decline does not meet the threshold specified under this criterion. An alternative criterion is a reduction of $>30 \%$, projected or expected within the next 10 years or three generations, whichever is the longer (criterion A3, IUCN 2001). The average rate of decline observed over the study interval exceeds the rate that would be necessary to halve the population in three generations, at least when our maximal estimate of generation time is used (21.6 years). The environmental precautionary principle suggests that we use this longer estimate of generation time for risk assessment. Even if the shorter estimate is used ( 14.7 years), the mean estimate is for a $53 \%$ decline over three generations, if the observed rate continues. These estimates clearly meet the requirements of this alternative criterion.

A more reliable long-term record of occupancy estimates will be crucial to determining whether decreases in burrow numbers translate to decreases in Sooty Shearwater breeding populations. Rigorous estimates of other Sooty Shearwater populations would also be beneficial for establishing whether the declines we observed on The Snares are occurring at the same rate throughout the species range, including the large breeding populations in Chile (Reyes-Arriagada et al. 2006). Recent reductions in shearwater bycatch (Uhlmann et al. 2005) and eradication of rats from four Sooty Shearwater breeding colonies (Moller et al. 2003b, Coote \& Blackwell 2006) may slow past declines, but other threats like climate change and harvesting continue. Clearly there is cause for concern for this abundant and important island ecosystem engineer species and the conservation values it affects. Ongoing and intensified monitoring of species abundance throughout the range of the Sooty Shearwater is required.

\section{ACKNOWLEDGEMENTS}

We are grateful to Kerry-Jayne Wilson and Graeme Taylor for constructive feedback on an earlier version of this paper. We thank Theresa Downs for help with revising the manuscript, and D. Russell, W. Hare, R. Blair, E. Summer, A. Booth, C. Powell, I. Söhle, K. Charleton and J. Newman for help with the fieldwork. We thank Land Information New Zealand for supplying a digital map of The Snares, J. Warham for permission to use C. Hay's vegetation map, J. Warham, K-J. Wilson and D. Horning for discussions about their study, and D. Houston for information about The Snares Crested-Penguin census. We thank P. Sagar and H. Moller for comments on the manuscript. Financial assistance was provided by the Foundation for Research, Science and Technology, University of Otago, and New Zealand Aluminium Smelters Ltd.

\section{REFERENCES}

Ainley, D.G., Veit, R.L., Allen, S.G., Spear, L.B. \& Pyle, P. 1995: Variations in marine bird communities of the California current, 1986-1994. California Cooperative Oceanic Fisheries Investigations Reports 36: 72-77. 
Artyukhin, Y.B. \& Burkanov, V.N. 2000: Incidental mortality of seabirds in the drift net salmon fishery by Japanese vessels in the Russian Exclusive Economic Zone, 1993-1997. In Kondratyev, A.Y., Litvineko, N.M. \& Kaiser, G.W. (eds): Seabirds of the Russian Far East. Ottawa, Canadian Wildlife Service Special publication: 105-116.

Bell, B.D. 1978: The Big South Cape Islands rat irruption. In Dingwall, P.R., Atkinson, I.A.E. \& Hay, C. (eds): The Ecology and Control of Rodents on New Zealand Nature Reserves. Department of Lands and Survey, Wellington, NZ: 33-45.

Bingham, M. 1998: The distribution, abundance and population trends of Gentoo, Rockhopper and King penguins in the Falkland Islands. Oryx 32: 223-232.

Bradley, J.S., Wooller, J.D. \& Skira, I.J. 1989: Age-dependant survival of breeding Short-Tailed Shearwaters Puffinus tenuirostris. Journal of Animal Ecology 58: 175-188.

Charleton, K.J. 2002: Variation in Sooty Shearwater burrow entrance density, burrow use and chick emergence: Science and Traditional Environmental Knowledge approaches. Unpublished MSc thesis, University of Otago, Dunedin.

Cochran, W.G. 1977: Sampling Techniques. Wiley, New York: 428 pp.

Collar, N.J., Crosby, M.J. \& Stattersfield, A.J. 1994: Birds to Watch 2; The World List of Threatened Birds. BirdLife International, Cambridge: $407 \mathrm{pp}$.

Coote, R. \& Blackwell, G. 2006: Rats removed! Titi Times 18: 2--3.

Cunningham, D.M. \& Moors, P.J. 1994: The decline of Rockhopper Penguins Eudyptes chrysocome at CampbellIsland, Southern Ocean and the influence of rising sea temperatures. Ети 94: 27-36.

Danchin, E., Gonzalezdavila, G. \& Lebreton, J.D. 1995: Estimating bird fitness correctly by using demographic models. Journal of Avian Biology 26: 67-75.

Davison, A.C. \& Hinkley, D.V. 1997: Bootstrap Methods and their Application. Cambridge University Press, Cambridge: 592 pp.

Falla, R.A. 1934: The distribution and breeding habits of petrels in northern New Zealand. Records of the Auckland Institute and Museum 1: 247-259.

Finkelstein, M., Bakker, V., Doak, D.F., Sullivan, B., Lewison, R., Satterthwaite, W.H., McIntyre, P.B., Wolf, S., Priddel, D., Arnold, J.M., Henry, R.W., Sievert, P. \& Croxall, J. 2008: Evaluating the potential effectiveness of compensatory mitigation strategies for marine bycatch. Plos. ONE 3(6): e2480. Doi:10.1371/journal. pone. 0002480 .

Furness, R.W. \& Camphuysen, C.J. 1997: Seabirds as monitors of the marine environment. I.C.E.S. Journal of Marine Science 54: 726-737.

Gaillard, J.M., Yoccoz, N.G., Lebreton, J.D., Bonenfant, C., Devillard, S., Loison, A., Pontier, D. \& Allaine, D. 2005: Generation time: a reliable metric to measure life-history variation among mammalian populations. The American Naturalist 166: 119-123.

Gould, P., Ostrom, P. \& Walker, W. 2000: Foods, trophic relationships, and migration of soory and short-tailed shearwaters associated with squid and large-mesh drifnet fisheries in the north Pacific Ocean. Waterbirds 23: $165-186$.

Guinard, E., Weimerskirch, H. \& Jouventin, P. 1998: Population changes and demography of the northern rockhopper penguin on Amsterdam and Saint Paul islands. Colonial Waterbirds 21: 222-228.

Hamilton, S.A. 1998: Determining burrow occupancy, fledging success and land-based threats to mainland and near-shore island sooty shearwater (Puffinus griseus) colonies. New Zealand Joumal of Zoology 25: 443-453.

Hamilton, S.A. 2000: How precise and accurate are data obtained using an infra-red scope for burrow-nesting Sooty Shearwaters (Puffinus griseus). Journal of Marine Ornithology 28: 1-6.

Hamilton, S., de Cruz, J., Hunter, C. \& Moller, H. 1998: An infrared scope for assessing sooty shearwater burrow occupancy. Conservancy Advisory Science Notes 187. Department of Conservation: $21 \mathrm{pp}$.

Hamilton, S.A. \& Moller, H. 1995: Can PVA models using computer packages offer useful conservation advice? Sooty Shearwaters Puffinus griseus in New Zealand as a case study. Biological Conservation 73: 107-117.

Hamilton, S.A., Moller, H. \& Robertson, C.J.R. 1997: Distribution of Sooty Shearwater (Puffinus griseus) breeding colonies along the Otago Coast, New Zealand, with indications of countrywide population trends. Notornis 44: $15-25$.

Hawke, D.J. \& Newman, J. 2005: Using isotope analysis to identify incorporation of marine nutrients in terrestrial birds at Snares Islands. Notornis 52: 108-111.

Hay, C.H., Warham, J. \& Fineran, B.A. 2004: 'The vegetation of The Snares, islands south of New Zealand, mapped and discussed. New Zealand Journal of Botany 42: 861-72.

Hilton, G.M., Thompson, D.R., Sagar, P.M., Cuthbert, R.J., Cherels, Y. \& Bury, S.J. 2006: A stable isotopic investigation into the causes of decline in a sub-Antarctic predator, the rockhopper penguin Eudyptes chrysocome. Global Change Biology 12: 1-15.

Horning, D.S. 1976: The 1974-1975 Snares Islands Expedition Department of Zoology, University of Canterbury, Christchurch: $61 \mathrm{pp}$.

Hunt, B.P.V., Pakhomov, E.A. \& McQuaid, C.D. 2001: Shortterm variation and long-term changes in the ocea nographic environment and zooplankton community in the vicinity of a sub-Antarctic archipelago. Marine Biology 138: 369-381.

Hunter, C.M. 2001: Demography of procellariids: harvesting, chick quality, and model complexity. Unpublished $\mathrm{PhD}$ thesis, University of Otago, Dunedin.

Hunter, C.M. \& Caswell, H. 2005: Selective harvest of sooty shearwater chicks: effects on population dynamics and sustainability. Journal of Animal Ecology 74(4): 589-600.

Hunter, C.M., Moller, H. \& Fletcher, D. 2000: Parameter uncertainty and elasticity analyses of a population model: setting research priorities for shearwaters. Ecological Modelling 134: 299-323.

Hurrell, J.W. \& Trenberth, K.E. 1999: Global sea surface temperature analyses: Multiple problems and their implications for climate analysis, modelling and reanalysis. Bulletin of the American Meteorological Society 80: 2661-2678.

Imber, M.J. 1987: Breeding ecology and conservation of the Black Petrel (Procellaria parkinsoni). Notornis 34: 19-39.

IUCN 2001: IUCN Red List of Threatened Species 2001 Categories \& Criteria (version 3.1), www.iucnredlist.org (accessed 22 January 2007).

Jones, C. 2000: Sooty Shearwater (Puffinus griseus) breeding colonies on mainland South Island, New Zealand: evidence of decline and predictors of persistence. New Zealand Journal of Zoology 27: 327-334.

Kitson, J.K. \& Moller, H. 2008: Looking after your ground: resource management practice by Rakiura Maori titi harvesters. Papers and Proceedings of the Royal Society of Tasmania 142(1): 161-176.

Lyver, P.O.B., Hamilton, S., McKenzie, M., Dickson, I., Dooher, T., Broad, T. \& Moller, H. 1998: A burrowscope for examining petrel nests in burrows. Conservation Advisory Science Notes 209: 21 pp.

Lyver, P.O.B, Moller, H. \& Thompson, C. 1999: Changes in Sooty Shearwater Puffinus griseus chick production and harvest precede ENSO events. Marine Ecology Progress 
Series 188: 237-248.

Mantua, N.J., Hare, S.R., Zhang, Y., Wallace, J.M. \& Francis, R.C. 1997: A Pacific inter-decadal climate oscillation with impacts on salmon production. Bulletin of the American Meteorological Society 78: 1069-1079.

McKechnie, S., Fletcher, D., Moller, H., Scott, D., Newman, J. \& Bragg, C. 2007: Estimating and correcting for bias in population assessments of sooty shearwaters. Joumal of Wildlife Management 71: 1325-1335.

McNally, N. 2001: New Zealand sea-lion population size and structure at peripheral colonies. Unpublished PGDipSci dissertation, University of Otago, Dunedin, New Zealand.

McNally, N. 2002: New Zealand sea lion abundance, demographics and movements in southern New Zealand. Unpublished MSc thesis, University of Otago, Dunedin.

Miskelly, C.M. 1999: Breeding ecology of Snares Island Snipe (Coenocorypha aucklandica huegeli) and Chatham Island Snipe (C. pusilla). Notornis 46: 207-221.

Miskelly, C.M., Sagar, P.M., Tennyson, A.J.D. \& Scofield R.P. (2001). Birds of the Snares Islands, New Zealand. Notornis 48: $1-40$.

Moller, H. 2006: Are current harvests of seabirds sustainable? Acta Zoologica Sinica 52 (Supplement): 649-652.

Moller, H., Frampton, C., Hocken, A.G., McLean, I.G., Saffer, V. \& Sheridan, L. 2000: The importance of seabird research for New Zealand. New Zealand Journal of Zoology 27: 255-260

Moller, H., Hunter, C.M., Howard, M., McSweeny, P., Scofield, P., Scott, D. \& Uren, S. 2003a: Automated system for measuring breeding burrows entry and exit by sooty shearwaters (Puffinus griseus). Department of Conservation Science Internal Series 129: $32 \mathrm{pp}$.

Moller, H., Nevins, H. \& Adams, J. 2003b: The Rakiura Tit restoration project: Mitigation of the Command oil spill injury by eradication of rats from Sooty Shearwater breeding colonies. A request to the Command Trustee Council for funding assistance: $71 \mathrm{pp}$.

Newman, J., Clucas, R., Moller, H., Fletcher, D., Bragg, C., Mckechnie, S. \& Scott, D. 2008: Sustainability of Tîtī harvesting by Rakiura Mãori: a synthesis report. University of Otago Wildlife Report (September 2008). University of Otago, Dunedin, New Zealand.

Newman, J., Fletcher, D., Moller, H., Harper, G., Bragg, C., Scott, D. \& McKechnie, S. In press: Improved estimates of breeding success for a burrow nesting petrel, the sooty shearwater (Puffinus griseus), from nine years of monitoring. Wildlife Research.

Oedekoven, C.S., Ainley, D.G. \& Spear, L.B. 2001: Variable responses of seabirds to change in marine climate: Californian Current, 1985-1994. Marine Ecology Progress Series 212: 265-281.

Ogi, H., Nitta, A. \& Hatanaka, H. 1991a: Effects of the Japanese squid driftnet fishery on the sooty and short-tailed shearwater populations. In Scientific Review of the North Pacific High Seas Driftnet Fisheries. Ecological Applications 3 Appendix 6(1): $20 \mathrm{pp}$.

Ogi, H., Yatsu, A. \& Hatanaka, H. $1991 \mathrm{~b}$ : Stock, status and mortality of some pelagic seabirds by the Japanese squid driftnet fishery. In Scientific Review of the North Pacific High Seas Driftnet Fisheries. Ecological Applications 3 Appendix 6(1): 25 pp.

Ogi, H., Yatsu, A., Hatanaka, H. \& Nitta, A. 1993: The mortality of seabirds by driftnet fisheries in the North Pacific. International North Pacific Fisheries Commission Bulletin 53: 499-518.

Reyes-Arriagada, R., Campos-Ellwanger, P., Schlatter, R.P. \& Baduini, C. 2006: Sooty shearwater (Puffinus griseus) on Guafo Island: the largest seabird colony in the world? Biodiversity Conservation. 16: 913-930.

Richdale, L.E. 1954: Duration of parental attentiveness in the sooty shearwater. Ibis 96: 586-600.

Richdale, L.E. 1963: Biology of the Sooty Shearwater Puffinus griseus. Journal of the Royal Society of New Zealand 141: $1-117$.

Robertson, C.J.R. 2000: Autopsy report for seabirds killed and returned from New Zealand fisheries 1 January 1998 to 30 September 1998. Department of Conservation, Wellington: $33 \mathrm{pp}$.

Russell, R.W. 1999: Comparative demography and life history tactics of seabirds: implications for conservation and marine monitoring. American Fisheries Society Symposium 23: $51-76$.

Ryan, P.G. \& Boix-Hinzen, C. 1999: Consistent male-biased seabird mortality in the Patagonian toothfish longline fishery. Auk 116: 851-854

Salinger, M.J. \& Mullan, A.B. 1999: New Zealand climate: Temperature and precipitation variations and their links with atmospheric circulation 1930-1994. International Joumal of Climatology 19: 1049-1071.

Scofield, R.P. 2000: Report on Titi Team trip to Titi Island, Marlborough Sounds. Nelson. Unpublished report to Department of Conservation.

Scofield, R.P. \& Christie, D. 2002: Beach patrol records indicate a substantial decline in sooty shearwater, Puffinus griseus numbers. Notornis 49: 158-165.

Scofield, R.P., Fletcher, D.J. \& Robertson, C.J.R. 2001: Titi (Sooty shearwaters) on Whero Island: analysis of historic data using modern techniques. Journal of Agricultural, Biological and Environmental Statistics 6: 269-280.

Scott, D.S. 2005: Burrow entrance densities of sooty shearwaters and mottled petrels on Whenua Hou. Unpublished PGDipSci dissertation, University of Otago, Dunedin.

Scott, D., Newman, J., Fletcher, D., Blackwell, G., McKechnie, S., Moller, H., Bragg, C. \& Nevins, H. 2006: Survey of Tìtī and mottled petrel abundance on Paopuka, Taukihepa. University of Otago Wildlife Management Report. Number No 801-2. 20 pp.

Shaffer, S.A., Tremblay, Y., Weimerskirch, H., Scott, D., Thompson, D.R., Sagar, P.M., Moller, H., Taylor, G.A., Foley, D.G., Block, B.A. \& Costa, D.P. 2006: Migratory shearwaters integrate oceanic resources across the Pacific Ocean in an endless summer. Proceedings of the National Academy of Sciences 103: 34, 12799-12802.

Skira, I. 1991: The short-tailed shearwater: a review of its biology. Corella 15: 45-52.

Taylor, R.H. 1967: Mammals and birds. In Burton, M.P. (ed.): Motunau Island, Canterbury, New Zealand: an Ecological Survey. DSIR, Nelson: 42-67.

Uhlmann, S. 2002: Accidental take of Sooty (Puffinus griseus) and Short-tailed shearwaters (P. tenuirostris) in fisheries. Unpublished MSc thesis, University of Otago, Dunedin.

Uhlmann, S. 2003: Fisheries bycatch mortalities of sooty shearwaters (Puffinus griseus) and short-tailed shearwaters (P. tenuirostris). DOC Science Internal Series 92. Department of Conservation, Wellington: $52 \mathrm{pp}$.

Uhlmann, S., Fletcher, D. \& Moller, H. 2005: Estimating incidental takes of shearwaters in driftnet fisheries: lessons for the conservation of seabirds. Biological Conservation 123: 151-163.

Veit, R., McGowan, J., Ainley, D., Wahls, T. \& Pyle, P. 1997: Apex marine predator declines ninety percent in association with changing oceanic climate. Global Change Biology 3: $23-28$.

Walsh, D., Kirkpatrick, J.B. \& Skira, I.J. 1997: Vegetation patterns, environmental correlates and vegetation change in a Puffinus tenuirostris breeding colony at Cape Queen Elizabeth, Tasmania. Australian Journal of Botany 45 $71-79$.

Warham, J. 1967: Snares Island birds. Notornis 14: 122-139.

Warham, J. 1990: The Petrels: their Ecology and Breeding Systems. 
London, Academic: $440 \mathrm{pp}$

Warham, J. 1996: The Behaviour, Population Biology and Physiology of the Petrels. London, Academic: $613 \mathrm{pp}$.

Warham, J., Keeley, B.R. \& Wilson, G.J. 1977: Breeding of the mottled petrel. Auk 94: 1-17.

Warham, J. \& Wilson, G. 1982: The size of the Sooty Shearwater population at the Snares Islands, New Zealand. Notorni 29: 23-30.

Warham, J., Wilson, G.J. \& Keeley B.R. 1982: The annual cycle of the Sooty Shearwater Puffinus griseus at the Snares Islands, New Zealand. Notomis 29: 269-292.

Weimerskirch, H. 1998: How can a pelagic seabird provision its chick when relying on a distant food resource? Cyclic attendance at the colony, foraging decision and body condition in sooty shearwaters. Journal of Animal Ecology 67: 99-109.

Wilcox, C. \& Donlan, C.J. 2007: Compensatory mitigation as a solution to fisheries bycatch - biodiversity conservation conflicts. Frontiers in Ecology or the Environment 5: $325-331$

Worm, B., Barbier, E.B., Beaumont, N., Duffy J.E., Folke, C., Halpern, B.J., Jackson, J.B.C., Lotze, H.K., Micheli, F., Palumbi, S.R., Sala, E., Selkoe, A., Stachowicz, J.J. \& Watson, R. 2006: Impacts of biodiversity loss on ocean ecosystem services. Science 314: 787-790.

(accepted 7 October 2008) 